\title{
Productivity and Sustainable Soil Health Management of Potato (Solanum tuberosum L.) Field as Influenced by Bio-fertilizers
}

\author{
Kamlesh Kumar Singh,* Anupma Kumari and Anupam Adarsh
}

Krishi Vigyan Kendra, Saraiya, Muzaffarpur - Dr. Rajendra Prasad Central Agricultural University, Pusa (Samastipur) Bihar - 848125, India

*Corresponding author

Keywords

Azotobacter, Biofertilizer, INM, PSB, Soil.

\section{Article Info}

Accepted:

15 December 2019

Available Online:

20 January 2020

\section{A B S T R A C T}

An On- farm trial were conducted during Rabi season of 2015-16 and 201617 at farmers field on pre-selected seven locations in Muzaffarpur district of Bihar considering farmers as replication to assess the efficacy of biofertilizers on yield and economics of potato. The results revealed that nutrient management of biofertilizer has statistically significant impact on tuber yield and economics as well as soil fertility status. The highest tuber yield (22.65 and 23.50 $\mathrm{ha}^{-1}$ ) was obtained significant in the treatment $\mathrm{N}_{120^{-}}$ $\mathrm{P}_{72}-\mathrm{K}_{100}$ along with Azotobacter $+\mathrm{PSB}$ as compared to $\mathrm{N}_{150}-\mathrm{P}_{90}-\mathrm{K}_{100}$ (RDF) as well as farmers practice. The maximum net return (Rs. $65375.00 \mathrm{ha}^{-1}$ and Rs.70250.00 ha ${ }^{-1}$ ) and $\mathrm{B}$ : C ratio (2.31 and 2.49) was found in $\mathrm{N}_{120}-\mathrm{P}_{72}-\mathrm{K}_{100}$ along with Azotobacter +PSB over $\mathrm{N}_{150}-\mathrm{P}_{90}-\mathrm{K}_{100}$ (RDF) and farmers practice. However,the seed treated with Azotobacter and PSB registered net positive balance of available nitrogen and phosphorus soil status over initial.

\section{Introduction}

Potato (Solanum tuberosum L.) is very popular and important vegetable grown all over world. It is the fourth important crop after maize, wheat and rice (FAO, 2009).Potato is a high yielding, nutrient exhaustive short duration crop which needs higher quantities of fertilizers. A normal potato crop yielding $30 \mathrm{t} / \mathrm{ha}$ removes about
$100 \mathrm{~kg} \mathrm{~N} \mathrm{ha}^{-1}$ from soil (Pandey et al., 2006). Soil fertility depletion and productivity are the matter of nutrient imbalance, which limits crop yield.

Nitrogen, phosphorus and potassium are the supplements of nutrient influencing development, improvement and yield of potato. The phosphorus directly affects shoot development, root advancement and tuber 
arrangement in potato while potassium is one of the vital constituent of cell and has impact on nature of tuber. Bio-fertilizers are biologically active products or microbial inoculants containing one or more beneficial bacteria orfungal strains in easy to use and economical carrier materials which conserve and mobilize crop nutrients in the soil.

Bio-fertilizer contains living microorganisms which when applied to seed, plant surfaces, or soil colonizes the rhizospehere or the interior of theplant and promotes growth by increasing theavailability of primary nutrients to the host plant (Mazid et al., 2011a).At present the terrestrial input of nitrogen from biological $\mathrm{N}_{2}$ fixation is held to be in the range of 139-170 X $106 \mathrm{t} \mathrm{N}$ per year as compared with $65 \mathrm{X} 106 \mathrm{t} \mathrm{N}$ per year provided by fertilizer nitrogen.

However, on average the relative contribution of symbiotic, associative and free-living $\mathrm{N}$ fixing systems is in the order of $70 \%$ symbiotic and $30 \%$ non-symbiotic. Maintaining the quality and sustainability of soil resources is a key issue, not only for optimizing the stability and productivity of natural ecosystems, but also to prevent erosion and minimize negative environmental stresses (Buscot, 2005). Integrated plant nutrient management has vital significance for the maintenance of soil productivity and boosting yield, reducing production cost and improving soil health are three inter-linked components of the sustainability triangle (Swarup,2010).

Keeping above mentioned facts and figures in point of view, the present investigation were taken up to study the effect of addition of Azotobacter and phosphorus-solublizing bacteria in supplementation of nutrient demand of potato (Solanum tuberosum L.) on yield and nutrient status of soil.

\section{Materials and Methods}

An On-farm trial was carried out during Rabi seasons of 2015-16 and 2016-17 under supervision of Krishi Vigyan Kendra, Sariya, Muzaffarpur (Bihar) on randomly preselected 07 farmers' fields as replication and each replication had the plot size of $300 \mathrm{~m}^{2}$. The study area are confined in Muzaffarpur district that lies between $24^{0} 54^{\prime}$ to $26^{\circ} 23^{\prime} \mathrm{N}$ latitudes, $84^{0} 53^{\prime}$ to $85^{\circ} 45^{\prime}$ E longitudes with altitude of $51.81 \mathrm{~m}$ above mean sea level, which falls under the part of Indo- Gangetic North-West Alluvial plain Zone of Bihar. The area has categorized as tropical humid to subhumid climate and having average rainfall $1234 \mathrm{~mm}$ with average temperature $25.3^{\circ} \mathrm{C}$ and relative humidity 67 percent.

The experiment was laid out in randomized block design (RBD) with seven replications. There were experiment comprised 3 treatments viz. T0 -Farmers practice, $\mathrm{T}_{1}-\mathrm{N}_{150}-$ $\mathrm{P}_{90}-\mathrm{K}_{100}(\mathrm{RDF})$ and $\mathrm{T}_{2}-20 \%$ reduce $\mathrm{RDF}$ $\left(\mathrm{N}_{120}: \mathrm{P}_{72}: \mathrm{K}_{100}\right)+$ Azotobacter, +phosphorussolublizing bacteria (PSB). The packets of Azotobacter and PSB containing 200gm inoculums were obtained from Department of Soil Science (Microbiology), TCA, Dholi, Muzaffarpur-Dr. Rajendra Prasad Central Agricultural University, Pusa, Samastipur, Bihar. Before sowing, Seed tubers treated with half $\mathrm{kg}$ each of Azotobacter and PSB bio-fertilizers were dissolved in 40 liters of water. Slurry was prepared by boiling $2 \mathrm{~kg}$ jaggary in one liter of water. After cooling, it was added to solution of bio-fertilizers. Potato tubers were dipped in the biofertilizer solution for 30 minutes as per treatment and shade dried.

Tubers were planted with spacing of $20.0 \mathrm{~cm}$ plant to plant distance while $60.0 \mathrm{~cm}$ apart from row to row. Prior to lay out the plot under the trial, soil samples were collected from each farmers' field separately and 
analyzed for available nitrogen by alkaline potassium permanganate method (Subbiah and Asija, 1956), available phosphorus was extracted using the method of $0.5 \mathrm{MNaHCO}_{3}$ extractable colorimetric method (Olsen et al, 1954) and available potassium was measured by shaking the required amount of soil sample with $1 \mathrm{~N} \mathrm{NH}_{4} \mathrm{OAc}(\mathrm{pH} 7.0)$ solution (1:5 soil: water solution ratio) for 5 minutes by Jackson (1973) method. All the selected experimental plots were received fertilizers as per treatment. Invariably, according to treatments, full dose of phosphorus and potassium applied as basal while nitrogen was applied in three splits i.e. 50 percent basal, 25 percent each at 40 and 55 DAS.

\section{Results and Discussion}

\section{Tuber yield of potato}

The effect of seed treatment with bio-fertilizer on tuber yield was studied after harvesting. Application of $\quad \mathrm{N}_{120}-\mathrm{P}_{72}-\mathrm{K}_{100}+$ Azotobacter+ phosphorus- solublizing bacteria significantly highest potato tuber yield were recorded (22.65 and 23.50t ha ${ }^{-1}$ ) over the rest of the treatments, whereas minimum values of tuber yield was associated with farmers practice in both the years of experimentation (Table 1). The above results are in close conformity with the findings of Nag (2006) regarding crop residue incorporation with bio-fertilizers (Azotobacter $+P S B)$ which produced the highest total tuber yield.

Similar results were also reported by Verma et al., (2011) in potato crop. Though, the treatment $T_{1}$ showed its statistical superior in respect to tuber yield over farmers practice $\left(T_{0}\right)$ in both the years. The effect of biological fertilizers containing nitrogen fixing bacteria and phosphate-solubilizing bacteria on the yield of agricultural crops has been investigated by Freitas (2000). Applying bio- fertilizers in potato crop significantly increased the tuber yield.

\section{Economics}

Net return (Rs.65375.00 $\mathrm{ha}^{-1}$ and Rs. $70250.00 \mathrm{ha}^{-1}$ ) and B:C ratio (2.31 and 2.49) under treatment $T_{2}$ was observed maximum among all the treatments but minimum Net return (Rs.60200.00 ha ${ }^{-1}$ and Rs.55050.00 ha ${ }^{-1}$ ) and Benefit : Cost ratio (2.27 and 2.22 ) was involved with treatment $T_{0}$ both the years of trial. It was attributed to reduction in cost of cultivation due to curtailing the chemical fertilizer dose as well as higher production under treatment $\mathrm{N}_{120}-\mathrm{P}_{75}-\mathrm{K}_{100}+$ Azotobacter + phosphorus - solublizing bacteria, where reduced chemical fertilizer was supplemented through Azotobacter + phosphorus solublizing bacteria with other beneficial effect of aforesaid bio-fertilizers. These findings were also reported by Shivakumar and Ahlawat (2008).

\section{Nitrogen and phosphorus status of soil}

The pooled data (Table 2) of two years of trial, found that treatment $\left(T_{2}\right)$ has net positive gain of available nitrogen and phosphorus as compared with rest treatments i.e. $\mathrm{T}_{1}$ and $\mathrm{T}_{0}$ and on the other hand, net loss of available nitrogen and phosphorus were observed in treatment $\mathrm{T}_{0}$. It indicates that uses of Azotobacter and phosphorus-solubilizing bacteria (PSB) together in the present experiment were cumulatively translated into net gain of available nitrogen and phosphorus.

They have the capacity to produce natural resistance in plants against pests and soil borne diseases, because antibodies are produced and beneficial micro-organisms participate in the soil to increase fertility (Board, 2004). There are two kinds of biofertilizers i.e. nitrogen bio- fertilizers and phosphatic 
Table.1 Effect of Bio-fertilizer (Azotobacter and PSB) on tuber yield and economics of potato

\begin{tabular}{|c|c|c|c|c|c|c|c|c|c|c|c|}
\hline \multirow{3}{*}{ Treatments } & \multicolumn{3}{|c|}{$\begin{array}{l}\text { Tuber yield } \\
\quad\left(\mathbf{t ~ h a}^{-1}\right)\end{array}$} & \multicolumn{8}{|c|}{$\begin{array}{c}\text { Economics } \\
\left(\mathbf{R s} . \mathbf{h a}^{-1}\right)\end{array}$} \\
\hline & \multirow[t]{2}{*}{ 2015-16 } & \multirow[t]{2}{*}{ 2016-17 } & \multirow[t]{2}{*}{ Pooled } & \multicolumn{4}{|c|}{ 2015-16 } & \multicolumn{4}{|c|}{ 2016-17 } \\
\hline & & & & $\begin{array}{c}\text { Cost of } \\
\text { cultivation }\end{array}$ & $\begin{array}{l}\text { Gross } \\
\text { return }\end{array}$ & $\begin{array}{c}\text { Net } \\
\text { return }\end{array}$ & B:C ratio & $\begin{array}{c}\text { Cost of } \\
\text { cultivation }\end{array}$ & $\begin{array}{l}\text { Gross } \\
\text { return }\end{array}$ & $\begin{array}{c}\text { Net } \\
\text { return }\end{array}$ & B:C ratio \\
\hline$T_{0}:$ Farmers Practice & 21.54 & 20.01 & 20.78 & 47500.00 & 107700.00 & 60200.00 & 2.27 & 45000.00 & 100050.00 & 55050.00 & 2.22 \\
\hline$T_{1}: \operatorname{RDF}\left(\mathbf{N}_{150}-P_{90}-K_{100}\right)$ & 22.44 & 22.50 & 22.47 & 49000.00 & 112215.00 & 63215.00 & 2.29 & 47000.00 & 112500.00 & 65500.00 & 2.39 \\
\hline $\mathrm{T}_{2}: \mathrm{N}_{120}-\mathrm{P}_{72}-\mathrm{K}_{100}+$ Azot. $_{\text {. }}+\mathrm{PSB}$ & 22.65 & 23.50 & 23.08 & 50000.00 & 115375.00 & 65375.00 & 2.31 & 47250.00 & 117500.00 & 70250.00 & 2.49 \\
\hline SEm \pm & 1.17 & 0.72 & 0.46 & 442.08 & 328.62 & 477.42 & - & 278.52 & 352.43 & 251.93 & - \\
\hline C. D. $(P=0.05)$ & 3.59 & 2.23 & 1.40 & 1361.98 & 1012.43 & 1470.86 & - & 858.09 & 1085.79 & 776.15 & - \\
\hline
\end{tabular}

Table.2 Effect of Bio-fertilizer (Azotobacter and PSB) on soil fertility

\begin{tabular}{|c|c|c|c|c|c|c|}
\hline \multirow{2}{*}{ Treatments } & \multicolumn{2}{|c|}{$\begin{array}{c}\text { Available Nitrogen } \\
\left(\mathrm{kg} \mathrm{ha}^{-1}\right)\end{array}$} & \multicolumn{2}{|c|}{$\begin{array}{l}\text { Available Phosphorus } \\
\left(\mathrm{kg} \mathrm{ha}^{-1}\right)\end{array}$} & \multicolumn{2}{|c|}{ Net change (net gain/loss) } \\
\hline & Initial & Post-harvest & Initial & Post-harvest & $\begin{array}{c}\text { Available } \\
\text { Nitrogen } \\
\left(\mathrm{kg} \mathrm{ha}^{-1}\right)\end{array}$ & $\begin{array}{c}\text { Available } \\
\text { Phosphorus } \\
\left(\text { kg ha }^{-1}\right)\end{array}$ \\
\hline$T_{0}:$ Farmers Practice & 213.29 & 212.73 & 28.50 & 28.05 & -0.56 & -0.45 \\
\hline $\mathrm{T}_{1}: \operatorname{RDF}\left(\mathrm{N}_{150}-\mathrm{P}_{90}-\mathrm{K}_{100}\right)$ & 224.95 & 224.81 & 30.00 & 29.96 & -0.14 & -0.04 \\
\hline $\mathrm{T}_{2}: \mathrm{N}_{120}-\mathrm{P}_{72}-\mathrm{K}_{100}+$ Azot. $+\mathrm{PSB}$ & 240.91 & 243.37 & 32.15 & 34.83 & 2.46 & 2.68 \\
\hline SEm \pm & 2.81 & 2.00 & 0.38 & 0.30 & - & - \\
\hline C. D. $(P=0.05)$ & 8.65 & 6.15 & 1.16 & 0.92 & - & - \\
\hline
\end{tabular}


Nitrogen bio-fertilizers add nitrogen to the dirt by diminishing environmental nitrogen and phosphatic bio-fertilizers can solubilize the phosphates bound in soil and builds its accessibility in plant. To build the creation and nature of potato, sensible blend of natural wellsprings of supplement alongside inorganic and bio-fertilizers (azotobacter, phosphobacteria) get great reaction Nag (2006).

It is free living and non-symbiotic N-fixing organism that also produces certain substances good for the growth of plants and antibodies that suppress many root pathogens. They improve seed germination and plant growth by producing vitamins, NAA, GA and other chemicals (plant hormones) that are inhibitory to certain root pathogens (Mazid et al., 2011b).

Application of bio-fertilizers, especially biological nitrogen fixation through integrated use by chemical fertilizers is most important strategy for integrated plant nutrient in sustainable management.It can be concluded that combined inoculation of potato tuber with Azotobactor and PSB showed significantly higher tuber yield, as compare to other treatments.

So, these two bio fertilizers (Azotobactor and PSB) along with normal doses of major other fertilizers like N,P and K may be recommended to the potato growers to get higher yields and to prevent losses and to increase the overall production of potato. In this way, Azotobactor plays healthful stimulatory and remedial part for the advantage of yield, which makes it a potential bio-manure for potato. Similarly, PSB solubilizes phosphorus from soil source and makes it available to plant.

\section{References}

Buscot, F. 2005. What are soils? In microorganisms in soil: Roles in genesis and functions, Buscot,F. and Varma, S. (edt.) Springer-Verlag, Heidel berg, Germany. Pp. 3-18.

De Freitas, J.R. 2000.Yield and nitrogen assimilation winter wheat (Triticumaestivum L.) inoculated with rhizo-bacteria. Pedobiologia44: 97-104.

FAO 2009 https://en.wikipedia.org/wiki/Food and Agriculture Organization

Jackson, M.L.1973. Soil chemical analysis, Prentice Hall of India Pvt. Ltd, New Delhi.

Mazid, M., Khan, T.A., Mohammad, F. 2011a.Potential of $\mathrm{NO}$ and $\mathrm{H}_{2} \mathrm{O}_{2}$ as signaling molecules in tolerance to abiotic stress inplants. Journal of Industrial Research \&Technology, 1(1): 56-68.

Mazid, M., Khan, T.A., Mohammad, F. 2011b. Cytokinins, A classical multifaceted hormonein plant system. Journal of Stress Physiology \&Biochemistry, 7(4): 347-368.

Nambiar, K. K. M. and Ghosh, A.B. 1984. Long term fertilizer experiment, research bulletin. Indian Agricultural Research Institute, New Delhi, Pp 102.

Nag, G.P. 2006.Integrated nutrient management in potato for Chhattisgarh plains. M. Sc. (Ag) Thesis IGKV, Raipur, 94-95.

Olsen, S.R., Cole, C.V., Watanabe, F.S. and Dean, L.A.1954. Estimation of available phosphorus in soils by extraction with sodium bicarbonate. Circular 939, United States Department of Agriculture, Washington, DC, USA. 19.

Pandey, S.K., Gopal, J., Kumar, V. and Singh, S.V. 2006. Catalogue of Indian potato cultivars. Central Potato Research Institute, Shimla, India. Technical Bull., 78: 51

Rice, C.W., Smith, M.S., Blevins, R.L., 1986. Soil nitrogen availability after long-term continuous no-tillage and conventional 
tillage corn production. Soil Sci. Soc. Am. J. 50, 1206-1210.

Shivakumar, B.G. and Ahlawat, I.P.S. 2008. Integrated nutrient management in soybean (Glycine max)- wheat ( Triticum aestivum) cropping system. Indian journal of Agronomy, 53 (4): 273-278.

Subbiah, B.V. and Asija, G. L. 1956. A rapid procedure for the estimation of available nitrogen in soils. Current Science. 25: 259-260.
Swarup, A. 2010.Intigrated plant nutrient supply and management strategies for enhancing soil quality, input use efficiency and crop productivity. $J$. Indian society of soil science.58 (1):2531

Verma, S. K., Asati, B.S., Tamrakar, S.K., Nanda, H.C., Gupta, C.R.2011. Effect of organic components on growth, yield and economic returns in potato. Potato J. 38(1):51-55.

\section{How to cite this article:}

Kamlesh Kumar Singh, Anupma Kumari and Anupam Adarsh. 2020. Productivity and Sustainable Soil Health Management of Potato (Solanum tuberosum L.) Field as Influenced by Bio-fertilizers. Int.J.Curr.Microbiol.App.Sci. 9(01): 1700-1705. doi: https://doi.org/10.20546/ijcmas.2020.901.187 